\title{
Glucocorticoid receptors in lung cancer: new perspectives
}

\author{
Kerryn M Taylor', David W Ray ${ }^{2}$ and Paula Sommer ${ }^{1}$ \\ 1Division of Genetics, School of Life Sciences, University of KwaZulu-Natal, Durban, South Africa \\ 2Manchester Centre for Nuclear Hormone Research and Disease, Institute of Human Development, \\ Faculty of Medical and Human Sciences, University of Manchester, Manchester, United Kingdom
}

\author{
Correspondence \\ should be addressed \\ to P Sommer \\ Email \\ Sommerp@ukzn.ac.za
}

\begin{abstract}
Proper expression of the glucocorticoid receptor (GR) plays an essential role in the development of the lung. GR expression and signalling in the lung is manipulated by administration of synthetic glucocorticoids (Gcs) for the treatment of neonatal, childhood and adult lung diseases. In lung cancers, Gcs are also commonly used as co-treatment during chemotherapy. This review summarises the effect of Gc monotherapy and co-therapy on lung cancers in vitro, in mouse models of lung cancer, in xenograft, ex vivo and in vivo. The disparity between the effects of pre-clinical and in vivo Gc therapy is commented on in light of the recent discovery of $G R$ as a novel tumour suppressor gene.
\end{abstract}

\author{
Key Words \\ - glucocortiocoid receptor \\ - lung cancer \\ - chemotherapy \\ - tumour suppressor
}

Journal of Endocrinology (2016) 229, R17-R28

\section{Lung cancer}

Lung cancers are the leading cause of cancer-related deaths worldwide and are thus a major therapeutic burden. While the incidence of lung cancer has plateaued in the developed world, it continues to increase in the developing world. Being predominantly caused by smoking, lung cancers have a poor prognosis with a combined 5-year survival rate of less than 20\% (Torre et al. 2015). Lung cancers show heterogeneity and are therefore classified into two major groups, non-small cell lung cancer (NSCLC) and small cell lung cancer (SCLC). NSCLCs account for over $80 \%$ of all lung cancers and include adenocarcinomas, squamous cell carcinomas and bronchioalveolar and large cell carcinomas. The remaining $15-20 \%$ of lung cancers show features of neuroendocrine differentiation and are classified as SCLC. Bronchioalveolar stem cells are postulated to play a role in NSCLC tumourigenesis, while a rare population of neuroendocrine cells or less differentiated cells are thought to be the progenitor cells for SCLC. However, the cell/s of origin for these different lung cancers have not been definitively described with recent studies revealing remarkable plasticity in the regenerative powers of various lung cell types, further complicating the matter (Semenova et al. 2015).

The driver mutations for NSCLC particularly have been well described, and mutation testing can be used for patient stratification and prescription of targeted therapy (Pao \& Girard 2011).

\section{The glucocorticoid receptor}

Glucocorticoids (Gcs) are a class of steroid hormones that function to maintain homeostasis. The effects of Gcs are mediated by the ubiquitously expressed glucocorticoid receptor (GR), an intracellular ligand-activated transcription factor and member of the nuclear receptor superfamily. The GR is encoded by a single copy gene on chromosome 5, spanning an area of $110 \mathrm{~kb}$ (Turner \& Muller 2005, Zhou \& Cidlowski 2005). There are numerous transcriptional and translational isoforms of the GR.

Published by Bioscientifica Ltd 
The precise reasons for this are not clearly delineated, but the tissue-specific expression of these isoforms as well as their subtle differences in function suggest that these may be a mechanism to generate the massive signalling diversity exhibited by the GR (Oakley \& Cidlowski 2011). The GR is a modular protein, organised into three major functional domains: the N-terminal domain, DNAbinding domain and C-terminal ligand-binding domain (Cruz-Topete \& Cidlowski 2015). Unliganded GR resides in the cytosol associated with a macromolecular complex of chaperone and other proteins. Upon Gc binding, the GR becomes hyperphosphorylated, causing conformational changes in the GR resulting in dissociation of the receptor from the inactive, cytoplasmic multiprotein complex. The hyperphosphorylated receptor subsequently dimerises and migrates to the nucleus, where the GR can bind to DNA directly to regulate transcription, tether to other DNA-bound transcription factors or bind directly to DNA and interact with neighbouring transcription factors. GR signalling can also mediate rapid, non-genomic effects, as well as modify chromatin to stimulate or suppress the expression of a plethora of target genes (Cruz-Topete \& Cidlowski 2015). The most well-described effects of Gc signalling are their anti-inflammatory properties, where liganded GR physically interacts with nuclear factor- $\mathrm{kB}$ (NF-kB) and AP-1, preventing their induction of pro-inflammatory genes.

\section{The role of the GR in lung development}

Development of the lung, characterised by branching morphogenesis and reciprocal endodermal-mesodermal interactions, begins at embryonic day (E) 9.5 in mouse and $\sim 28$ days in human with the formation of primary lung buds. These buds extend into the mesenchyme and begin the process of branching morphogenesis. The initial stage of branching morphogenesis, the 'pseudoglandular' stage, is characterized by proliferation and growth resulting in the formation of tree-like structures ending in terminal tubules. In the following stages, the 'canilicular' stage (E16.5-E17.5) and the 'saccular' stage (E17.5-postnatal P5), these tubules begin the process of differentiation into alveoli precursors, the functional units for gaseous exchange. Progression from the pseudoglandular stage is accompanied by a surge in Gc secretion and an increase in the expression of the GR in the lung, suggesting that the GR plays a role in organ maturation. The mesoderm surrounding the lung buds plays an important role in development as a source of spatio-temporal signals driving differentiation (Morrisey \& Hogan 2010).

The presence of a functional GR is essential for normal lung development. The precise signalling mechanisms are not understood but it is accepted that Gc exposure acts to expand the proximal and distal airways and thin the intervening mesenchymal tissue, allowing for optimal gaseous exchange. Null and conditional $G r$-knockout mice die at or just after birth, displaying severe lung abnormalities and respiratory failure (Cole et al. 1995, Tronche et al. 1999, Brewer et al. 2002). The lungs of these $G r$ knockouts appear normal until E15.5 but subsequently show hypercellularity, with the severity of the phenotype modulated by genetic background. The observed hypercellularity is due to an increased proliferation rate rather than a lack of Gc-induced apoptosis (Bird et al. 2015). This onset coincides with the Gc surge which occurs at $\sim$ E14.5 in mice, towards the end of the pseudoglandular stage. In humans, the Gc surge occurs just before birth (Rog-Zielinska et al. 2014). GR activity in the mesenchymal compartment of the lung is currently thought to drive the correct development of the lung. Specific ablation of the GR in mesenchymal cells has been created by crossing GR ${ }^{\mathrm{fl} / \mathrm{fl}}$ with mice that express Cre under the control of the promoter/enhancer unit of the gene for the $\alpha 2$ chain of collagen type I (Col1 $\alpha 2)$. Such mice recapitulate the phenotype of $G r$-null mice, showing increased proliferation in the lung and a high incidence of neonatal mortality (Habermehl et al. 2011). GR deletion specific to the mesenchyme was also accomplished using other mesenchymal markers, Dermo1/Twist2 (Li et al. 2013, Bird et al. 2014). These mice show similar effects although varying in severity. Bird et al. (2015) suggest that the variation in lethality in these latter models is possibly due to incomplete GR deletion in the mesenchyme in these two models. An important consequence of this observation points to the necessity of a threshold level of GR in the mesenchyme necessary for proper lung development.

\section{Gc therapy and the lung}

Since their discovery more than seven decades ago, Gcs remain among the most widely prescribed drugs worldwide. Inhaled corticosteroids are commonly used to treat asthma based on their potent anti-inflammatory action. As the landmark publication showing that antenatal steroids markedly reduce respiratory distress and neonatal mortality in infants born before 34 weeks of gestation

Published by Bioscientifica Ltd. 
(Liggins \& Howie 1972), corticosteroid treatment has become standard of care. This is based on the developmental action of Gcs wherein administration of synthetic Gcs act to accelerate maturation of type 2 alveolar cells, thus increasing surfactant production in premature babies, and to regulate sodium channels to enable rapid clearance of liquid from the lung during the transition to air-breathing (Bourbon et al. 2009). While pre-term Gc administration is undoubtedly lifesaving, accumulated evidence suggests that it is not without consequences. For example, excess Gc exposure has longer term effects on neurodevelopment (Waffarn \& Davis 2012) and cardiovascular development (Rog-Zielinska et al. 2014).

Gcs are also used as primary treatment of haematological malignancies based on their ability to massively induce apoptosis of lymphoid cells (Herold et al. 2006). However, relapse is common due to acquired resistance (Schmidt et al. 2004).

It is generally thought that Gcs have no such apoptotic effects in solid, non-haematological tumours, but are nonetheless widely prescribed as adjuvant treatment for most cancers to alleviate symptoms caused by either the tumour or the cancer treatment such as inflammation, pain, nausea and allergic reactions.

\section{The effects of Gc monotherapy on lung cancers}

The effects of Gc monotherapy are described below and summarised in Fig. 1A.

\section{The effects of Gc monotherapy on NSCLC}

In vitro It has long been established that sufficient levels of the GR are necessary for responsiveness to stimulation (Dong et al. 1990); in haematological cancers, a correlation between GR content and Gc response has been shown (Vanderbilt et al. 1987). Gcs, acting through the GR, have diverse effects on cell lines, inhibiting growth, inducing apoptosis or promoting survival. The synthetic Gc, dexamethasone, has long been shown to exhibit growth-inhibitory effects on several GR-rich NSCLC cell lines (Hofmann et al. 1995). More recently, Gcs such as dexamethasone and budesonide have been shown to inhibit the proliferation of A549 cells, a GR-rich adenocarcinomaderived human alveolar epithelial cell line (Greenberg et al. 2002, Gundisch et al. 2012, Liang et al. 2014) with growth arrest thought to be accomplished by inhibition of retinoblastoma $(\mathrm{Rb})$ phosphorylation, preventing progression from $G_{1}$ to $S$ phase (Greenberg et al. 2002). In contrast, however, to the majority of published studies, dexamethasone enhanced the proliferation of the Calu-6 cell line (described as a pulmonary NSCLC cell line) both in vitro and in xenograft (Gundisch et al. 2012) suggesting that the specific lung cancer type as well as GR content of the cells may play a role in response to Gcs.

Liang et al. (2014) showed, using A549 cells (with wild-type p53) and SK-MES-1 (squamous lung carcinoma cells that are $p 53$ deficient), that the anti-proliferative effect of synthetic Gcs requires functional p53. p53 expression has also been shown to be necessary for Gc-mediated cell cycle arrest and apoptosis in MC3T3-E1 (osteoblast) cells (Li et al. 2012). p53 acts as a general inhibitor of inflammation, antagonising NF- $\mathrm{BB}$. Although the precise mechanism is unknown, p53 is thought to be required for liganded GR repression of NF-кB (Murphy et al. 2011). $\mathrm{NF}-\kappa \mathrm{B}$ is constitutively active in most cancers and many lung cancers have mutations in p53 (Gudkov et al. 2011). This may offer a possible explanation as to why Gcs cannot significantly reduce inflammation in tumour cells. In p53null H1299 cells (a lung adenocarcinoma cell line) that also express low levels of the GR, dexamethasone had no effect on cell proliferation; however, the inhibitory effects on proliferation were restored by restoring GR expression ectopically in these cells. High levels of GR in this context may, therefore, be sufficient to overcome the lack of p53 (Patki et al. 2014).

These in vitro studies predominantly show that Gc treatment has growth-inhibitory effects on NSCLC cell lines, most of which are GR abundant, and, to a lesser extent, that p53 plays a role in mediating the dexamethasone growth-suppressive effects in vitro.

In chemically induced lung cancer tumours Lung tumours can be chemically induced in mice by treatment with cigarette smoke, cigarette smoke carcinogens such as nicotine-derived nitrosamine ketone (NNK) or benzo(a)pyrene (BP), or classic carcinogens such as vinyl carbamate. The majority of tumours produced by these methods are classified as adenomas or adenocarcinomas (NSCLCs) (Meuwissen \& Berns 2005). In strain H mice with cigarette-smoking-induced tumours, the administration of budesonide upon weaning or after cessation of exposure to cigarette smoke decreased both the incidence and multiplicity of lung tumours (Balansky et al. 2010). A potential mechanism for this was revealed in an in vitro

Published by Bioscientifica Ltd. 
A Glucocorticoid Monotherapy

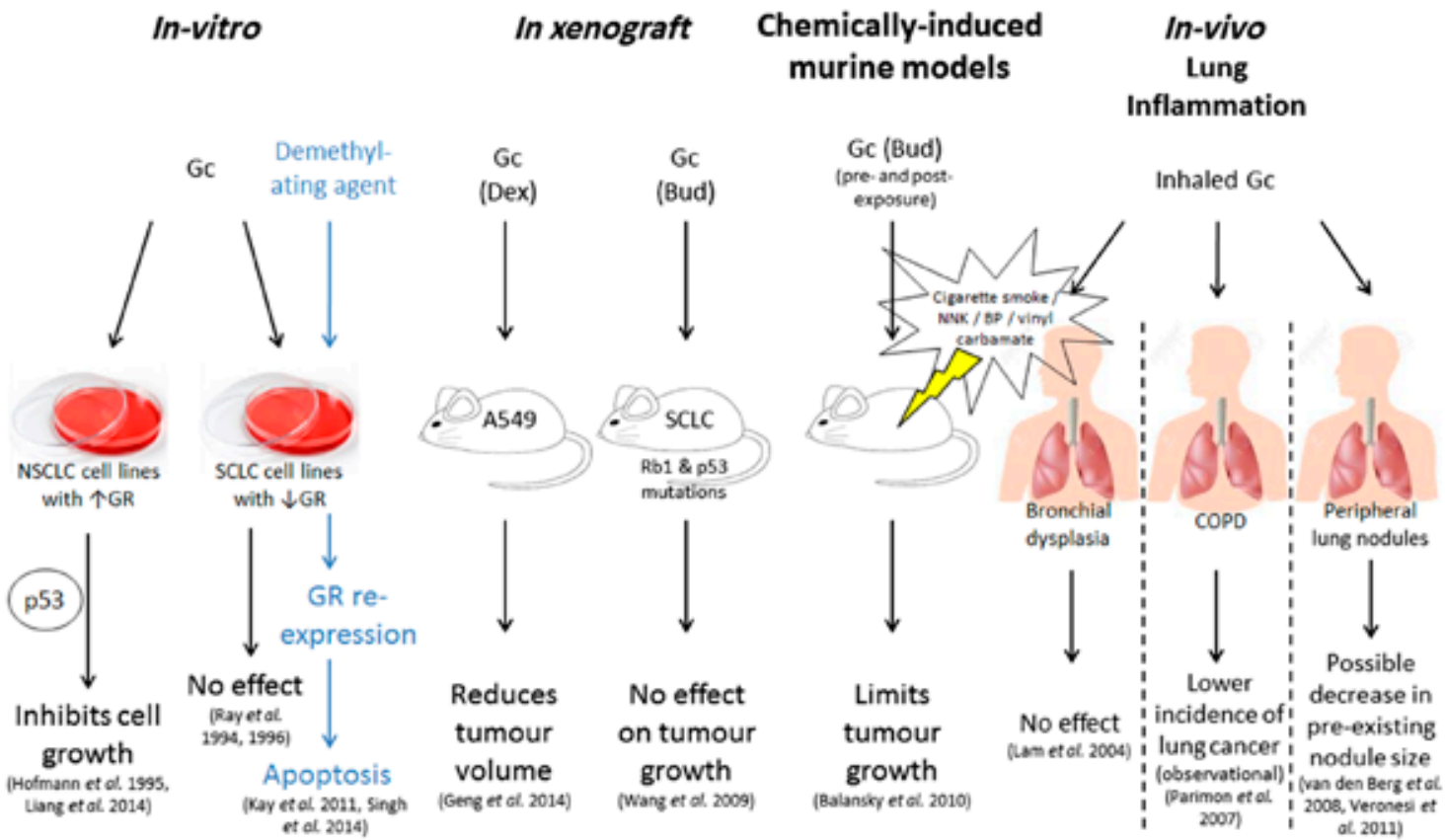

B Glucocorticoid Co-treatment

In-vitro

Pemetrexed/

cisplatin + Dex

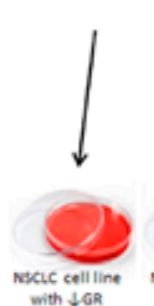

wCLC cell line

$\downarrow$

cheme-therapy

(Pastiet al 2014)

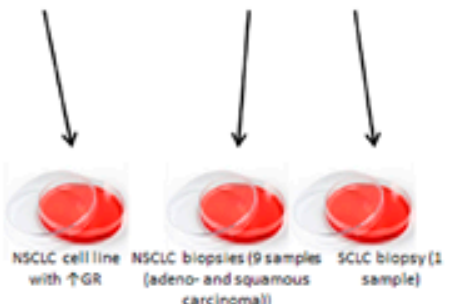

carcingma)!
Ex-vivo

Cisplatin/ Gemcitabine + Dex

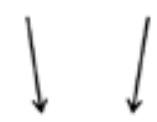

Reduces sensithily to cisplatin batke et of 201
In xenograft

Cisplatin + Dex

Dexpre-

treatment +

carboplatin/

gemcitabine

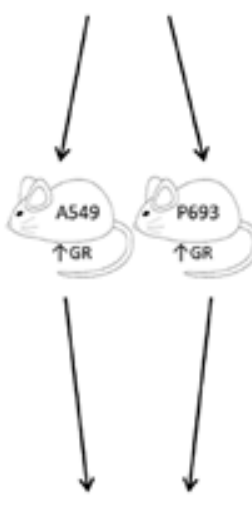

Inhibits cisplatin effects

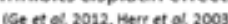

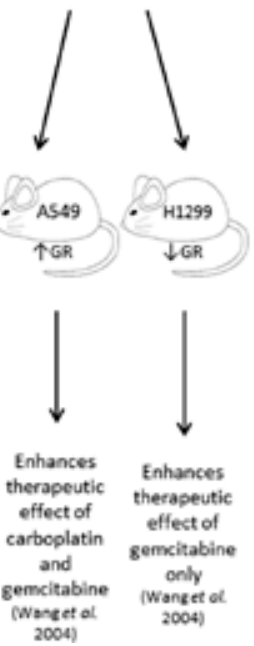

In-vivo

Cyclophosphamide Teniposide+ +/-prednisolone GC

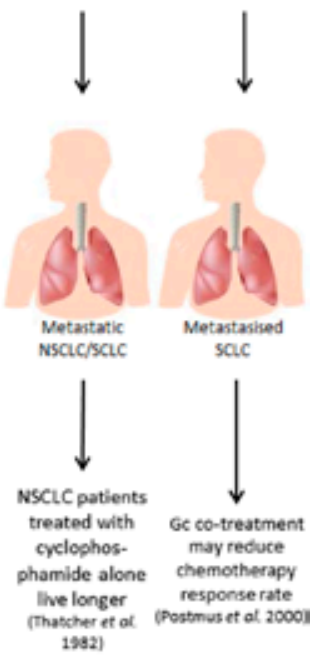

Figure 1

Summary of the effects of Gc monotherapy (A) and co-treatment (B) on lung cancer in in vitro, in xenograft, chemically-induced mouse models and in vivo situations. Dex, dexamethasone; Bud, budesonide; COPD, chronic obstructive pulmonary disease.

http://joe.endocrinology-journals.org DOI: 10.1530/JOE-15-0496
() 2016 Society for Endocrinology Printed in Great Britain
Published by Bioscientifica Ltd. 
study using A549 cells treated with cigarette smoke extract where dexamethasone significantly, and dosedependently, decreased the apoptotic effect of the extract via upregulation of Hsp72, acting to inhibit caspase action (Gal et al. 2011). Similarly, both pre-treatment of $\mathrm{A} / \mathrm{J}$ mice with budesonide prior to exposure to the cigarette carcinogen BP, and budesonide treatment after BP exposure, protected against tumour formation with efficacy decreasing when administered in late-stage carcinogenesis (Wang et al. 2003, Fu et al. 2011). In NNK-induced and vinyl-carbamate-induced lung tumours, budesonide administration reduced tumour size (Alyaqoub et al. 2006, Casto \& Pereira 2011). These experiments suggest that, in these murine models of chemically induced lung cancer, Gc treatment shows efficacy as an anti-tumour agent when administered prior to exposure and during exposure to cigarette carcinogens but its efficacy is reduced when administered at late-stage cancer.

Mice from the A/J strain are highly susceptible to chemically induced lung tumours but such induced tumours do not generally display mutations in p53 (Wang et al. 2003), one of the most frequently mutated genes in lung cancer (Gibbons et al. 2014). In a BP-induced model of lung cancer in mice harbouring mutations in p53 and/or Ink4a/Arf (Cdkn2a), the ability of budesonide to limit tumour growth is significantly affected, suggesting that these two genes are important in budesonidemediated chemo-preventative effects (Wang et al. 2003). This study again highlights the importance of $p 53$ in playing a role in the mediation of the anti-proliferative effects of Gcs. This is interesting as many lung tumours harbour p53 mutations (46\% in lung adenocarcinoma and $81 \%$ in squamous cell carcinoma) and most clinical studies suggest that lung cancers with $p 53$ mutations carry a worse prognosis and are more resistant to treatment (Gibbons et al. 2014).

In xenograft models of lung cancer In xenografts created with A549 cells, a combination treatment of drugs thought to act on the tumour microenvironment (dipyridamole, bestatin and dexamethasone) significantly reduced tumour weight (Liu et al. 2014), while in the Lewis lung-tumour bearing mice, treatment with dexamethasone decreased tumour volume (Geng et al. 2014).

Thus, the evidence from both in vitro and in xenograft studies and mouse models suggests that Gc monotherapy can have a negative effect on tumour growth.
In vivo These growth-delaying effects seen in controlled, genetically homogenous cell lines in vitro and in xenograft experiments do not appear to be translated to the genetically heterogenous in vivo situation. Early case series and randomised controlled trials performed in the 1960s on patients with advanced lung cancer (summarised in (Keith 2008)) showed that Gc monotherapy on lung cancer patients had no survival benefits.

More recent in vivo studies primarily focus on the effects of inhaled Gc treatment in patients with different manifestations of lung inflammation. Chronic inflammation plays a crucial role in tumourigenesis and such inflammation may be present in pre-cancerous individuals.

A randomised, double blind, placebo controlled phase IIb trial was performed to determine the effects of inhaled budesonide in smokers with bronchial dysplasia. Patients were selected for their high risk of lung cancer and given either budesonide or placebo for 6 months. Despite the evidence in xenograft, there was no difference between the budesonide and placebo groups. The authors postulate that the discrepancy may lie in that the xenograft models are primarily adenocarcinoma, while the patients in this study were primarily at risk for squamous cell carcinoma (Lam et al. 2004).

An observational epidemiological study performed on data from patients diagnosed with chronic obstructive pulmonary disease (COPD) found that inhaled corticosteroid use resulted in a lower incidence of lung cancer (Parimon et al. 2007). COPD is a risk factor for lung cancer because of its association with smoking and inflammation.

Clinical trials have been performed to determine the effects of inhaled Gcs on patients with lung nodules. More subjects had a decrease and fewer had an increase in the number of nodules detected on chest CT (although this trend did not reach statistical significance) or Gcs had no effect on the formation of new lesions (van den Berg et al. 2008). However, pre-existing non-solid or partially solid nodules that have a greater chance of progressing to adenocarcinoma decreased in size after treatment (Veronesi et al. 2011).

The results of these pre-cancerous studies are conflicting with inhaled budesonide having either no survival effect, or showing a slight decrease in either the incidence of lung cancer (although observational) or a trend towards a decrease in new nodule formation, or a decrease in existing nodule size.
Published by Bioscientifica Ltd. 


\section{The effects of Gc treatment on SCLC}

In vitro The effects of GCs on SCLC cell lines are not well described. Earlier studies showed that SCLC cell lines are generally Gc resistant due to mutations in the GR (Ray et al. 1994, 1996). Later exploration of this resistance revealed that SCLC cell lines also contain reduced GR content compared to NSCLC (Sommer et al. 2007, Kay et al. 2011, Schlossmacher et al. 2013). Furthermore, re-expression by retroviral over-expression both in vitro and in xenograft resulted in apoptotic induction, prompting us to postulate that loss of GR expression may play a role in tumourigenesis and to speculate that a threshold level of the GR is required for GR activity in SCLC cells (Sommer et al. 2007, 2010). We later showed that the reduction in GR is due to silencing by methylation (Kay et al. 2011, Singh et al. 2014). Unpublished preliminary data show that, although heterogenous, there are distinct differences in the methylation profile of the GR promoter in patients diagnosed with NSCLC and SCLC.

In xenograft In contrast to the chemically induced mouse models of lung cancer and the xenograft studies described in the previous section which are predominantly NSCLC, in a model of SCLC (mice harbouring mutations in both $R b 1$ and p53), budesonide treatment did not have a statistically significant effect on tumour growth. This is possibly due to the low levels of GR in SCLC but also may be compounded by the loss of p53 (Wang et al. 2009).

\section{The effect of Gcs when used as co-treatment in lung cancer}

The use of Gcs as co-treatment in chemotherapy has long been under debate in pre-clinical studies (reviewed in Herr et al. 2007). A summary of the effects of Gcs as co-treatment in lung cancers is presented in Table 1 and depicted in Fig. 1B.

\section{In vitro}

In vitro studies using a variety of different NSCLC cell lines show that dexamethasone treatment affects sensitivity to pemetrexed or cisplatin chemotherapy (Herr et al. 2003, Gassler et al. 2005, Ge et al. 2012, Patki et al. 2014). The importance of sufficient GR is highlighted as dexamethasone effects are not dependent on p53 but rather dependent on the GR status, as dexamethasone treatment did not influence pemetrexed effects on H1299 cells (which contain low levels of GR $\alpha$ ) (Patki et al. 2014). Lack of sensitivity to pemetrexed action was restored in H1299 cells transduced with exogenous GR and pretreated with dexamethasone for $48 \mathrm{~h}$ (Patki et al. 2014). Dexamethasone pre-treatment for $24 \mathrm{~h}$ also decreased sensitivity towards cisplatin in GR-containing $\mathrm{H} 460$ NSCLC cells (Lu et al. 2005).

\section{In xenograft}

Dexamethasone treatment prevented tumour growth inhibitory effects of cisplatin in xenografts created with A549 (Ge et al. 2012) and P693 (squamous lung cancer) cells (Herr et al. 2003). Both A549 and P693 cells are known to express high levels of GR, and apoptosis sensitivity was partially restored in vitro by treatment with the GR antagonist, RU486 (Herr et al. 2003), suggesting a direct role for GR activity in interfering with cisplatin action by disruption of death signalling pathways.

Most chemotherapy agents are toxic and suppress bone marrow leading to neutropenia or thrombocytopenia. Dexamethasone is known to affect the tumour microenvironment by reducing tumour interstitial fluid and may have haemoprotective activity. In a study aimed at principally addressing these chemotherapy side effects, murine xenografts were created with A549 (p53 wild-type, GR-rich) and H1299 (p53 null with low GR content) cells. Pre-treatment with dexamethasone $(0.1 \mathrm{mg} /$ day/mouse for 5 days) increased the therapeutic effect of carboplatin and gemcitabine for A549 xenografts, and gemcitabine only for H1299 xenografts. Dexamethasone pre-treatment alone did not have a significant effect on tumour growth but did, interestingly, increase tumour gemcitabine concentrations (Wang et al. 2004). This study differs from the other xenograft studies in that it uses pre-treatment rather than co-treatment and also uses an unusually high dose of dexamethasone.

\section{Ex vivo}

In ex vivo studies, where cells were grown from biopsy tissue material from adenocarcinoma and squamous carcinoma (all at least T2-4 but M0) and one SCLC (T2M0) biopsy, cisplatin and gemcitabine treatment reduced cell viability, but co-treatment with dexamethasone reduced this growth inhibition effect (Gassler et al. 2005).

Published by Bioscientifica Ltd. 
Table 1 Summary of the effects of Gcs when used as co-treatment during chemotherapy of lung cancers.

\begin{tabular}{|c|c|c|c|c|c|c|c|c|}
\hline \multirow{2}{*}{$\begin{array}{l}\text { Lung } \\
\text { cancer type }\end{array}$} & \multirow{2}{*}{$\begin{array}{l}\text { Classification/ } \\
\text { subtype }\end{array}$} & \multicolumn{4}{|c|}{ Study type } & \multirow[b]{2}{*}{ Treatment } & \multirow[b]{2}{*}{ Finding } & \multirow[b]{2}{*}{ Reference } \\
\hline & & In vitro & In xenograft & Ex vivo & In vivo & & & \\
\hline$\overline{\mathrm{NSCLC}}$ & 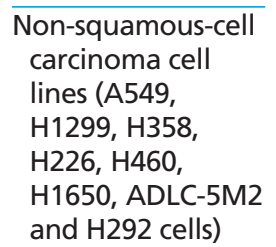 & $\bar{\checkmark}$ & & & & $\begin{array}{l}\text { Co-treatment with } \\
100 \mathrm{nM} \text { Dex for } 48 \mathrm{~h}\end{array}$ & $\begin{array}{l}\text { Reduces chemother- } \\
\text { apeutic effect of } \\
\text { pemetrexed in } \\
\text { GR-rich A549 cells } \\
\text { but not in GR-poor } \\
\text { H1299 cells }\end{array}$ & $\begin{array}{l}\text { Patki } \\
\text { et al. } \\
\text { (2014) }\end{array}$ \\
\hline NSCLC & $\mathrm{H} 460$ & $\checkmark$ & & & & $\begin{array}{l}\text { Pre-treatment with } \\
1 \mathrm{mmol} / \mathrm{L} \text { Dex for } 24 \mathrm{~h} \\
\text { followed by cisplatin }\end{array}$ & $\begin{array}{l}\text { Reduces chemother- } \\
\text { apeutic effect of } \\
\text { cisplatin }\end{array}$ & $\begin{array}{l}\text { Lu et al. } \\
\text { (2005) }\end{array}$ \\
\hline \multirow[t]{2}{*}{ NSCLC } & $\begin{array}{l}\text { A549, } \mathrm{NCl}-\mathrm{H} 292 \\
\text { and } \mathrm{NCl}-\mathrm{H} 1299 \\
\text { cells }\end{array}$ & $\checkmark$ & & & & $\begin{array}{l}\text { Co-treatment with } 1 \mu \mathrm{M} \\
\text { Dex for } 48 \mathrm{~h}\end{array}$ & $\begin{array}{l}\text { Reduces chemother- } \\
\text { apeutic effect of } \\
\text { cisplatin }\end{array}$ & $\begin{array}{l}\text { Ge et al. } \\
(2012)\end{array}$ \\
\hline & A549 cells & & $\checkmark$ & & & $\begin{array}{l}\text { Co-treatment of } \\
0.2 \mathrm{mg} / \mathrm{kg} \text { Dex on the } \\
\text { day before, day of and } \\
\text { day after cisplatin } \\
\text { injection when tumours } \\
\text { reached } 200 \mathrm{~mm}^{3}\end{array}$ & $\begin{array}{l}\text { Reduces chemother- } \\
\text { apeutic effect of } \\
\text { cisplatin }\end{array}$ & \\
\hline NSCLC & $\begin{array}{l}\text { P693 cells (squa- } \\
\text { mous carcinoma } \\
\text { cells) }\end{array}$ & & $\checkmark$ & & & $\begin{array}{l}\text { Co-treatment of } \\
0.28 \mathrm{mg} / \mathrm{L} \text { Dex along } \\
\text { with cisplatin treat- } \\
\text { ment when tumours } \\
\text { reached } 500 \mathrm{~mm}^{3}\end{array}$ & $\begin{array}{l}\text { Reduces chemother- } \\
\text { apeutic effect of } \\
\text { cisplatin }\end{array}$ & $\begin{array}{l}\text { Herr et al. } \\
(2003)\end{array}$ \\
\hline \multirow[t]{2}{*}{ NSCLC } & A549 (p53 wt) cells & & $\checkmark$ & & & $\begin{array}{l}\text { Pre-treatment with } \\
0.1 \mathrm{mg} / \mathrm{day} / \mathrm{mouse} \text { Dex } \\
\text { for } 5 \text { days followed by } \\
\text { carboplatin or } \\
\text { gemcitabine }\end{array}$ & $\begin{array}{l}\text { Enhances chemother- } \\
\text { apeutic effect of } \\
\text { carboplatin and } \\
\text { gemcitabine in } \\
\text { GR-rich, p53 } \\
\text { wild-type A549 cells }\end{array}$ & $\begin{array}{l}\text { Wang } \\
\text { et al. } \\
\text { (2004) }\end{array}$ \\
\hline & $\begin{array}{l}\text { H1299 (p53 null) } \\
\text { cells }\end{array}$ & & $\checkmark$ & & & & $\begin{array}{l}\text { Enhances chemo- } \\
\text { therapeutic effect } \\
\text { of gemcitabine } \\
\text { only in GR-poor, } \\
\text { p53 null H1299 cells }\end{array}$ & \\
\hline $\begin{array}{l}\text { NSCLC and } \\
\text { one SCLC }\end{array}$ & $\begin{array}{l}\text { Cells grown from } \\
\text { biopsy material } \\
\text { from five } \\
\text { adenocarcinomas } \\
\text { and four } \\
\text { squamous cell } \\
\text { carcinomas (T2-4, } \\
\text { M0) and } 1 \text { SCLC } \\
\text { (T2M0) biopsy }\end{array}$ & & & $\checkmark$ & & $\begin{array}{l}\text { Pre-treatment with } \\
0.1-10 \mu \mathrm{M} \text { Dex for } 24 \mathrm{~h} \\
\text { followed } \\
\text { by cisplatin or } \\
\text { gemcitabine }\end{array}$ & $\begin{array}{l}\text { Heterogeneity in } \\
\text { data but overall } \\
\text { reduction in } \\
\text { chemotherapeutic } \\
\text { effect of cisplatin } \\
\text { or gemcitabine }\end{array}$ & $\begin{array}{l}\text { Gassler } \\
\text { et al. } \\
\text { (2005) }\end{array}$ \\
\hline SCLC & Metastatic & & & & $\checkmark$ & $\begin{array}{l}\text { Corticosteroid co-treat- } \\
\text { ment (for peri- } \\
\text { tumoural oedema } \\
\text { only) with teniposide }\end{array}$ & $\begin{array}{l}\text { Corticosteroid } \\
\text { co-treatment } \\
\text { appeared to reduce } \\
\text { chemotherapeutic } \\
\text { effect of teniposide }\end{array}$ & $\begin{array}{l}\text { Postmus } \\
\text { et al. } \\
\text { (1995) }\end{array}$ \\
\hline $\begin{array}{l}\text { NSCLC and } \\
\text { SCLC }\end{array}$ & Metastatic & & & & $\checkmark$ & $\begin{array}{l}\text { Cyclophosphamide } \\
\text { alone or in combina- } \\
\text { tion with prednisolone }\end{array}$ & $\begin{array}{l}\text { Prednisolone } \\
\text { co-treatment } \\
\text { appeared to reduce } \\
\text { patient survival }\end{array}$ & $\begin{array}{l}\text { Thatcher } \\
\text { et al. } \\
(1982)\end{array}$ \\
\hline NSCLC & Advanced & & & & $\checkmark$ & $\begin{array}{l}\text { Pre-treatment with } 8 \text { or } \\
16 \text { mg Dex twice a day, } \\
4 \text { days before and on } \\
\text { day of chemotherapy }\end{array}$ & $\begin{array}{l}\text { Pre-treatment with } \\
\text { high doses reduces } \\
\text { haematological } \\
\text { toxicity }\end{array}$ & $\begin{array}{l}\text { Leggas } \\
\text { et al. } \\
\text { (2009) }\end{array}$ \\
\hline NSCLC & Stage IV & & & & $\checkmark$ & $\begin{array}{l}\text { Pre-treatment with } 16 \text { mg } \\
\text { Dex twice a day, } 4 \text { days } \\
\text { before and on Days } 1 \\
\text { and } 8 \text { of chemotherapy }\end{array}$ & $\begin{array}{l}\text { Pre-treatment with } \\
\text { high doses reduces } \\
\text { haematological } \\
\text { toxicity }\end{array}$ & $\begin{array}{l}\text { Rinehart } \\
\text { et al. } \\
(2013)\end{array}$ \\
\hline $\begin{array}{l}\text { http://] } \\
\text { DOI: } 1\end{array}$ & 15-0496 & & & & & & & \\
\hline
\end{tabular}


The dexamethasone effects were heterogenous but still showed partial protection against cisplatin-induced death, prompting the authors to suggest the use of non-steroidal agents for management of nausea.

\section{In vivo}

In 1982, a study was performed to determine whether high doses of cyclophosphamide could be effective at prolonging life span in patients with metastatic NSCLC and SCLC. Since cyclophosphamides cause bone marrow suppression, the study tested whether addition of prednisolone to the regimen could ameliorate toxicity. The addition of prednisolone did not improve the therapeutic efficacy of cyclophosphamide nor did it ameliorate toxicity. The study did show, however, that NSCLC patients treated with cyclophosphamide alone lived significantly longer than patients treated with cyclophosphamide plus prednisolone. Although not commented on in this study, this suggests that prednisolone administration in NSCLC may interfere with chemotherapy (Thatcher et al. 1982).

Similar negative effects on chemotherapy were reported in a phase II study (Postmus et al. 1995). Although not the primary objective, in a study to determine the efficacy of teniposide on patients diagnosed with SCLC that had metastasised to the brain, corticosteroid co-treatment (administered in patients with peritumoural oedema only) resulted in a significantly reduced chemotherapy response rate, resulting in the authors cautioning the use of corticosteroids during chemotherapy of brain metastases. Interestingly, in a phase III follow on of this trial, the effects of Gc were not tested (Postmus et al. 2000).

These earlier studies, coupled with in vitro and in xenograft data, show that dexamethasone treatment appears to counter the effects of the chemotherapy agents on solid tumours, prompting a viewpoint in the Lancet in 2002 cautioning use of corticosteroid co-treatment (Rutz 2002). Although primarily focused on prostate cancers, a similar stance was taken in a review in 2007 (Herr et al. 2007); a systematic meta-analysis in 2008 concluded that both Gc monotherapy and co-therapy had a deleterious effect on lung cancer (Keith 2008).

Despite this evidence, there are no more recently published data from clinical trials aimed primarily at determining the effects of Gc treatment on lung cancer. More recent studies have focused on the use of Gcs to ameliorate the toxic effects (such as haematological toxicity) of chemotherapy. In a phase I/II trial to determine the optimal dose of dexamethasone pre-treatment to reduce chemo-induced haematopoetic toxicity, patients with NSCLC stage $3 \mathrm{~B} / 4$ were given 8 or $16 \mathrm{mg}$ dexamethasone 4 days before and on the day of chemotherapy. Dexamethasone treatment was shown to reduce haematological toxicity (assessed by nadir absolute granulocyte count (AGC) and platelet counts). The primary and secondary end points of the study were not designed to determine the effect of dexamethasone co-treatment with carboplatin and gemcitabine. For its favourable effects on preventing toxicity, the authors promote the use of high doses of dexamethasone pre-treatment (Leggas et al. 2009).

Based on these findings this same research group performed a randomised phase II trial of carboplatin and gemcitabine with or without dexamethasone in untreated patients with Stage IV NSCLC. The protocol was designed to test the hypothesis that dexamethasone pre-treatment reduced toxicity of chemotherapy in patients with Stage IV NSCLC. The primary endpoint of the study was haematological toxicity. Dexamethasone treatment reduced haematological toxicity but had no effect on non-haematological toxicity or quality of life. Although the authors suggest that dexamethasone enhances the chemotherapeutic response, overall dexamethasone treatment did not significantly affect survival (Rinehart et al. 2013).

In more recent studies comparing chemotherapy agents, dexamethasone is given to all patient groups (Schmid-Bindert et al. 2013, Xu et al. 2015) and has, along with other anti-emetic agents, been recommended as co-treatment for patients undergoing cisplatin treatment (Kitazaki et al. 2015).

Pre-clinical data show predominantly that dexamethasone co-treatment has a negative effect on chemotherapy. These pre-clinical data are predominantly collected in genetically homogenous cell lines and inbred animal models where both GR content and p53 are known. Early studies suggest that this negative effect may be extended to a genetically heterogenous patient population; however, this has not been explored with newer studies focusing primarily on the positive effects of dexamethasone in reducing inflammation, alleviating allergic response and preventing nausea.

\section{The GR as a TSG for lung cancer}

In SCLC, we have shown that the expression of the GR exerts an anti-survival effect on SCLC cells in vitro and

Published by Bioscientifica Ltd. 
in xenograft (Sommer et al. 2007, 2010), suggesting that silencing of the GR plays a role in SCLC tumourigenesis. Our work showed that SCLC cell lines contained reduced GR transcripts when compared to NSCLC cell lines. A recent report has extended these observations to show that the GR appears downregulated in many cancers including liver, prostate, colon and breast (Matthews et al. 2015). In SCLC, GR downregulation occurs due to methylation of the GR promoter (Kay et al. 2011, Singh et al. 2014). Others have shown that in ovarian cancer, BRCA1 is a potential regulator of the GR, possibly through phosphorylation of Ser211 and entry of GR into the nucleus. GR is thus decreased in BRCA1-mutated ovarian cancer (Fang et al. 2014).

The GR promoter is similarly silenced in gastric and colorectal cancers suggesting that GR silencing may play a global role in tumour development. GR expression was also shown to be decreased in breast cancer patients compared to non-malignant tissue along with frequent GR promoter methylation (Nesset et al. 2014). In breast cancer, unliganded GR interacts with BRCA1. Thus, loss of GR from the BRCA1 promoter as a result of Gc stimulation leads to reduced BRCA1 expression, which may contribute to the development of sporadic breast tumours which do not show mutations in BRCA1 (Ritter et al. 2012). Decreased GR expression, therefore, appears to be a ubiquitous and important event, leading to the suggestion that the GR is a TSG in the breast as high GR expression is correlated with anti-proliferative signalling. Importantly, genetic heterogeneity influences this effect as loss of GR has a better outcome in ER - breast cancer but a poorer outcome in ER+ breast cancer, indicating that GR effects in breast cancer may be tumour sub-type dependent (Ritter et al. 2012). The GR has also been postulated to act as a tumour suppressor in skin and prostate cancers (Chebotaev et al. 2007, Yemelyanov et al. 2007).

A recent study has definitively shown that the GR is an authentic TSG (Matthews et al. 2015). Aged GR haploinsufficient mice display increased numbers of microtumours and DNA damage compared to their wildtype counterparts and, in cultured B lymphocytes from patients with GR haploinsufficiency, the chromosome complement was significantly lower than from unaffected family members. The report elegantly demonstrates a novel, non-transcriptional role for the GR in mitosis where the GR localises to the spindle centrosome during metaphase and anaphase of mitosis. Here, the GR is phosphorylated at multiple sites by Aurora A (Aurka), a kinase associated with the centrosome whose presence is vital for mitotic progression. Loss of the GR at the spindle resulted in a delayed metaphase and transition to anaphase, thought to be caused by errors in chromosome segregation. Rescue from this phenotype was prevented by the loss of the ligand-binding domain of the GR; however, ligand binding does not appear to be required for chromosome segregation suggesting a role for the domain in protein-protein interaction. These data point to an important role for the GR regulating mitotic progression. GR loss results in errors in chromosome segregation leading to aneuploidy and eventually carcinogenesis (Matthews et al. 2015).

\section{Conclusions}

Expression of the GR is intimately linked to the lung. Sufficient GR levels are required for proper lung development and its developmental and postdevelopmental activity in the lung has been exploited for the treatment of neonatal, childhood and adult lung disorders.

Gc monotherapy of NSCLC cell lines and xenografts predominantly shows that Gc treatment is growth inhibitory. These growth-inhibitory effects are limited by low levels of the GR and mutations in p53. In murine models of chemically induced lung cancers, Gc treatment shows efficacy as an anti-tumour agent when administered prior to exposure and during exposure, but efficacy is reduced when administered at late-stage cancer. Once again, growth-limiting effects are dependent on the presence of functional GR and p53. This is evidenced in SCLC cell lines and xenografts which are generally Gc resistant due to low levels of the GR. In these studies, the growth-inhibitory effects of the GR are thought to be due to growth arrest mediated by a wide variety of different mechanisms including GR inhibition of cyclin D and augmentation of p21 and p27 expression (Rogatsky et al. 1997). The effect of Gc monotherapy in vivo is conflicting. Not surprisingly, given the availability of lung-cancerspecific chemotherapy, there are no recent studies which use Gc monotherapy as a treatment for lung cancer. All the studies discussed in this review delineate the effects of Gc monotherapy on patients with different manifestations of lung inflammation, a possible precursor to lung cancer. In these cases, monotherapy has little effect although some studies show a slight decrease in lung nodule growth.

There is overwhelming evidence from pre-clinical studies that Gcs, when used as co-treatment during chemotherapy for lung cancers, interfere with

Published by Bioscientifica Ltd. 
chemotherapy action, promoting growth by preventing death signalling. The ability of Gc co-therapy to interfere with chemotherapy has been attributed to a number of different actions such as enhancing the resistance of cancer cells to chemotherapy-induced apoptosis by inhibition of key pro-apoptotic and upregulation of antiapoptotic molecules (Herr et al. 2003) or activation of pro-survival Stat5 (STAT5A)/Bcl-xL (BCL2L1) pathways (Qian et al. 2009). Again, sufficient GR levels are necessary and the presence of p53 may play a role in mediating these Gc effects. In xenograft models, Gc pre-treatment prior to chemotherapy at very high doses was shown to enhance chemotherapeutic effects, possibly through its haemoprotective action. Two clinical trials also demonstrate that Gc pre-treatment may have beneficial effects by reducing haematological toxicity. Although older clinical studies and many pre-clinical studies suggest that Gc co-treatment during chemotherapy has a deleterious effect, Gcs are administered routinely as part of the chemotherapy regimen.

It is interesting that Gc monotherapy causes growth arrest but, in the presence of chemotherapyinduced apoptosis, acts in a variety of ways to protect against apoptosis. Both of these actions, described beautifully in vitro and in xenografts, however, depend on the presence of sufficient GR levels and partly on the presence of functional p53, both of which are highly variable in the in vivo situation.

Recent work has shown that the GR is a TSG for lung cancer, with unliganded GR playing an important role in chromosome segregation during mitosis. Loss of the GR, therefore, can result in transformation.

It is therefore possible that the deleterious effects of Gc administration shown in vitro and in xenografts, where the GR content and p53 status are known, may not translate to the clinical setting where genetic heterogeneity exists and GR and p53 status do not play a role in patient stratification. Furthermore, GR downregulation as part of the tumourigenic process may leave the cancers less likely to respond to its effects, and allow other tissues with normal GR content to respond appropriately.

\section{Declaration of interest}

There is no conflict of interest that could be perceived as prejudicing the impartiality of the research reported.

\section{Funding}

This work was supported by a National Research Foundation grant (CSUR13091641336). Printed in Great Britain

\section{References}

Alyaqoub FS, Tao L, Kramer PM, Steele VE, Lubet RA, Gunning WT \& Pereira MA 2006 Prevention of mouse lung tumors and modulation of DNA methylation by combined treatment with budesonide and R115777 (ZarnestraMT). Carcinogenesis 27 2442-2447. (doi:10.1093/ carcin/bgl088)

Balansky R, Ganchev G, Iltcheva M, Steele VE \& De Flora S 2010 Prevention of cigarette smoke-induced lung tumors in mice by budesonide, phenethyl isothiocyanate, and N-acetylcysteine. International Journal of Cancer 126 1047-1054. (doi:10.1002/ijc.24942)

Bird AD, Choo YL, Hooper SB, McDougall AR \& Cole TJ 2014 Mesenchymal glucocorticoid receptor regulates the development of multiple cell layers of the mouse lung. American Journal of Respiratory Cell and Molecular Biology 50 419-428. (doi:10.1165/rcmb.20130169OC)

Bird AD, McDougall AR, Seow B, Hooper SB \& Cole TJ 2015 Glucocorticoid regulation of lung development: lessons learned from conditional GR knockout mice. Molecular Endocrinology 29 158-171. (doi:10.1210/me.2014-1362)

Bourbon JR, Boucherat O, Boczkowski J, Crestani B \& Delacourt C 2009 Bronchopulmonary dysplasia and emphysema: in search of common therapeutic targets. Trends in Molecular Medicine 15 169-179. (doi:10.1016/j.molmed.2009.02.003)

Brewer JA, Kanagawa O, Sleckman BP \& Muglia LJ 2002 Thymocyte apoptosis induced by $\mathrm{T}$ cell activation is mediated by glucocorticoids in vivo. Journal of Immunology 169 1837-1843. (doi:10.4049/ jimmunol.169.4.1837)

Casto BC \& Pereira MA 2011 Prevention of mouse lung tumors by combinations of chemopreventive agents using concurrent and sequential administration. Anticancer Research 31 3279-3284.

Chebotaev D, Yemelyanov A \& Budunova I 2007 The mechanisms of tumor suppressor effect of glucocorticoid receptor in skin. Molecular Carcinogenesis 46 732-740. (doi:10.1002/mc.20349)

Cole TJ, Blendy JA, Monaghan AP, Krieglstein K, Schmid W, Aguzzi A, Fantuzzi G, Hummler E, Unsicker K \& Schutz G 1995 Targeted disruption of the glucocorticoid receptor gene blocks adrenergic chromaffin cell development and severely retards lung maturation. Genes \& Development 9 1608-1621. (doi:10.1101/gad.9.13.1608)

Cruz-Topete D \& Cidlowski JA 2015 One hormone, two actions: anti- and pro-inflammatory effects of glucocorticoids. Neuroimmunomodulation 22 20-32. (doi:10.1159/000362724)

Dong Y, Cairns W, Okret S \& Gustafsson JA 1990 A glucocorticoidresistant rat hepatoma cell variant contains functional glucocorticoid receptor. Journal of Biological Chemistry 265 7526-7531.

Fang YY, Li D, Cao C, Li CY \& Li TT 2014 Glucocorticoid receptor repression mediated by BRCA1 inactivation in ovarian cancer. BMC Cancer 14 188. (doi:10.1186/1471-2407-14-188)

Fu H, Zhang J, Pan J, Zhang Q, Lu Y, Wen W, Lubet RA, Szabo E, Chen R, Wang Y et al. 2011 Chemoprevention of lung carcinogenesis by the combination of aerosolized budesonide and oral pioglitazone in A/J mice. Molecular Carcinogenesis 50 913-921. (doi:10.1002/mc.20751)

Gal K, Cseh A, Szalay B, Rusai K, Vannay A, Lukacsovits J, Heemann U, Szabo AJ, Losonczy G, Tamasi L et al. 2011 Effect of cigarette smoke and dexamethasone on Hsp72 system of alveolar epithelial cells. Cell Stress Chaperones 16 369-378. (doi:10.1007/s12192-010-0249-z)

Gassler N, Zhang C, Wenger T, Schnabel PA, Dienemann H, Debatin KM, Mattern J \& Herr I 2005 Dexamethasone-induced cisplatin and gemcitabine resistance in lung carcinoma samples treated ex vivo. British Journal of Cancer 92 1084-1088. (doi:10.1038/sj.bjc.6602453)

Ge H, Ni S, Wang X, Xu N, Liu Y, Wang X, Wang L, Song D, Song Y \& Bai C 2012 Dexamethasone reduces sensitivity to cisplatin by blunting p53-dependent cellular senescence in non-small cell lung cancer. PLoS One 7 e51821. (doi:10.1371/journal.pone.0051821)

Published by Bioscientifica Ltd 
Geng Y, Wang J, Jing H, Wang HW \& Bao YX 2014 Inhibitory effect of dexamethasone on Lewis mice lung cancer cells. Genetics and Molecular Research 13 6827-6836. (doi:10.4238/2014.August.29.4)

Gibbons DL, Byers LA \& Kurie JM 2014 Smoking, p53 mutation, and lung cancer. Molecular Cancer Research 12 3-13. (doi:10.1158/1541-7786. MCR-13-0539)

Greenberg AK, Hu J, Basu S, Hay J, Reibman J, Yie TA, Tchou-Wong KM, Rom WN \& Lee TC 2002 Glucocorticoids inhibit lung cancer cell growth through both the extracellular signal-related kinase pathway and cell cycle regulators. American Journal of Respiratory Cell and Molecular Biology 27 320-328. (doi:10.1165/rcmb.4710)

Gudkov AV, Gurova KV \& Komarova EA 2011 Inflammation and p53: a tale of two stresses. Genes \& Cancer 2 503-516. (doi:10.1177/ 1947601911409747)

Gundisch S, Boeckeler E, Behrends U, Amtmann E, Ehrhardt H \& Jeremias I 2012 Glucocorticoids augment survival and proliferation of tumor cells. Anticancer Research 32 4251-4261.

Habermehl D, Parkitna JR, Kaden S, Brugger B, Wieland F, Grone HJ \& Schutz G 2011 Glucocorticoid activity during lung maturation is essential in mesenchymal and less in alveolar epithelial cells. Molecular Endocrinology 25 1280-1288. (doi:10.1210/me.2009-0380)

Herold MJ, McPherson KG \& Reichardt HM 2006 Glucocorticoids in T cell apoptosis and function. Cellular and Molecular Life Sciences 63 60-72. (doi:10.1007/s00018-005-5390-y)

Herr I, Ucur E, Herzer K, Okouoyo S, Ridder R, Krammer PH, von Knebel Doeberitz M \& Debatin KM 2003 Glucocorticoid cotreatment induces apoptosis resistance toward cancer therapy in carcinomas. Cancer Research 63 3112-3120.

Herr I, Gassler N, Friess H \& Buchler MW 2007 Regulation of differential pro- and anti-apoptotic signaling by glucocorticoids. Apoptosis 12 271-291. (doi:10.1007/s10495-006-0624-5)

Hofmann J, Kaiser U, Maasberg M \& Havemann K 1995 Glucocorticoid receptors and growth inhibitory effects of dexamethasone in human lung cancer cell lines. European Journal of Cancer 31A 2053-2058.

Kay P, Schlossmacher G, Matthews L, Sommer P, Singh D, White A \& Ray D 2011 Loss of glucocorticoid receptor expression by DNA methylation prevents glucocorticoid induced apoptosis in human small cell lung cancer cells. PLoS One 6 e24839. (doi:10.1371/journal.pone.0024839)

Keith BD 2008 Systematic review of the clinical effect of glucocorticoids on nonhematologic malignancy. BMC Cancer 884 . (doi:10.1186/1471-2407-8-84)

Kitazaki T, Fukuda Y, Fukahori S, Oyanagi K, Soda H, Nakamura Y \& Kohno S 2015 Usefulness of antiemetic therapy with aprepitant, palonosetron, and dexamethasone for lung cancer patients on cisplatin-based or carboplatin-based chemotherapy. Supportive Care in Cancer 23 185-190. (doi:10.1007/s00520-014-2339-4)

Lam S, leRiche JC, McWilliams A, Macaulay C, Dyachkova Y, Szabo E, Mayo J, Schellenberg R, Coldman A, Hawk E et al. 2004 A randomized phase IIb trial of pulmicort turbuhaler (budesonide) in people with dysplasia of the bronchial epithelium. Clinical Cancer Research $\mathbf{1 0}$ 6502-6511. (doi:10.1158/1078-0432.CCR-04-0686)

Leggas M, Kuo KL, Robert F, Cloud G, deShazo M, Zhang R, Li M, Wang H, Davidson S \& Rinehart J 2009 Intensive anti-inflammatory therapy with dexamethasone in patients with non-small cell lung cancer: effect on chemotherapy toxicity and efficacy. Cancer Chemotherapy and Pharmacology 63 731-743. (doi:10.1007/ s00280-008-0767-x)

Li H, Qian W, Weng X, Wu Z, Li H, Zhuang Q, Feng B \& Bian Y 2012 Glucocorticoid receptor and sequential P53 activation by dexamethasone mediates apoptosis and cell cycle arrest of osteoblastic MC3T3-E1 cells. PLoS One 7 e37030. (doi:10.1371/ journal.pone.0037030)

Li A, Hardy R, Stoner S, Tuckermann J, Seibel M \& Zhou H 2013 Deletion of mesenchymal glucocorticoid receptor attenuates embryonic lung development and abdominal wall closure. PLoS One 8 e63578. (doi:10.1371/journal.pone.0063578)
Liang H, Kowalczyk P, Junco JJ, Klug-De Santiago HL, Malik G, Wei SJ \& Slaga TJ 2014 Differential effects on lung cancer cell proliferation by agonists of glucocorticoid and PPARalpha receptors. Molecular Carcinogenesis 53 753-763. (doi:10.1002/mc.22029)

Liggins GC \& Howie RN 1972 A controlled trial of antepartum glucocorticoid treatment for prevention of the respiratory distress syndrome in premature infants. Pediatrics 50 515-525.

Liu XJ, Zheng YB, Li Y, Wu SY \& Zhen YS 2014 A multifunctional drug combination shows highly potent therapeutic efficacy against human cancer xenografts in athymic mice. PLoS One 9 e115790. (doi:10.1371/journal.pone.0115790)

Lu YS, Lien HC, Yeh PY, Yeh KH, Kuo ML, Kuo SH \& Cheng AL 2005 Effects of glucocorticoids on the growth and chemosensitivity of carcinoma cells are heterogeneous and require high concentration of functional glucocorticoid receptors. World Journal of Gastroenterology 11 6373-6380. (doi:10.3748/wjg.v11.i40.6373)

Matthews LC, Berry AA, Morgan DJ, Poolman TM, Bauer K, Kramer F, Spiller DG, Richardson RV, Chapman KE, Farrow SN et al. 2015 Glucocorticoid receptor regulates accurate chromosome segregation and is associated with malignancy. PNAS 112 5479-5484. (doi:10.1073/pnas.1411356112)

Meuwissen R \& Berns A 2005 Mouse models for human lung cancer. Genes \& Development 19 643-664. (doi:10.1101/gad.1284505)

Morrisey EE \& Hogan BL 2010 Preparing for the first breath: genetic and cellular mechanisms in lung development. Developmental Cell 18 8-23. (doi:10.1016/j.devcel.2009.12.010)

Murphy SH, Suzuki K, Downes M, Welch GL, De Jesus P, Miraglia LJ, Orth AP, Chanda SK, Evans RM \& Verma IM 2011 Tumor suppressor protein (p)53, is a regulator of NF-kappaB repression by the glucocorticoid receptor. PNAS 108 17117-17122. (doi:10.1073/pnas.1114420108)

Nesset KA, Perri AM \& Mueller CR 2014 Frequent promoter hypermethylation and expression reduction of the glucocorticoid receptor gene in breast tumors. Epigenetics 9 851-859. (doi:10.4161/ epi.28484)

Oakley RH \& Cidlowski JA 2011 Cellular processing of the glucocorticoid receptor gene and protein: new mechanisms for generating tissuespecific actions of glucocorticoids. Journal of Biological Chemistry $\mathbf{2 8 6}$ 3177-3184. (doi:10.1074/jbc.R110.179325)

Pao W \& Girard N 2011 New driver mutations in non-small-cell lung cancer. Lancet Oncology 12 175-180. (doi:10.1016/S14702045(10)70087-5)

Parimon T, Chien JW, Bryson CL, McDonell MB, Udris EM \& Au DH 2007 Inhaled corticosteroids and risk of lung cancer among patients with chronic obstructive pulmonary disease. American Journal of Respiratory and Critical Care Medicine 175 712-719. (doi:10.1164/rccm.2006081125OC)

Patki M, Gadgeel S, Huang Y, McFall T, Shields AF, Matherly LH, Bepler G \& Ratnam M 2014 Glucocorticoid receptor status is a principal determinant of variability in the sensitivity of non-smallcell lung cancer cells to pemetrexed. Journal of Thoracic Oncology 9 519-526. (doi:10.1097/JTO.0000000000000111)

Postmus PE, Smit EF, Haaxma-Reiche H, van Zandwijk N, Ardizzoni A, Quoix E, Kirkpatrick A, Sahmoud T \& Giaccone G 1995 Teniposide for brain metastases of small-cell lung cancer: a phase II study. European Organization for Research and Treatment of Cancer Lung Cancer Cooperative Group. Journal of Thoracic Oncology 13 660-665.

Postmus PE, Haaxma-Reiche H, Smit EF, Groen HJ, Karnicka H, Lewinski T, van Meerbeeck J, Clerico M, Gregor A, Curran D et al. 2000 Treatment of brain metastases of small-cell lung cancer: comparing teniposide and teniposide with whole-brain radiotherapy a phase III study of the European Organization for the Research and Treatment of Cancer Lung Cancer Cooperative Group. Journal of Thoracic Oncology 18 3400-3408.

Qian YH, Xiao Q, Chen H \& Xu J 2009 Dexamethasone inhibits camptothecin-induced apoptosis in C6-glioma via activation of

Published by Bioscientifica Ltd 
Stat5/Bcl-xL pathway. Biochimica et Biophysica Acta 1793 764-771. (doi:10.1016/j.bbamcr.2009.01.017)

Ray DW, Littlewood AC, Clark AJ, Davis JR \& White A 1994 Human small cell lung cancer cell lines expressing the proopiomelanocortin gene have aberrant glucocorticoid receptor function. Journal of Clinical Investigation 93 1625-1630. (doi:10.1172/JCI117143)

Ray DW, Davis JR, White A \& Clark AJ 1996 Glucocorticoid receptor structure and function in glucocorticoid-resistant small cell lung carcinoma cells. Cancer Research 56 3276-3280.

Rinehart J, Arnold S, Kloecker G, Lim A, Zaydan MA, Baeker T, Maheshwari JG, Carloss H, Slone S, Shelton B et al. 2013 Phase II randomized trial of carboplatin and gemcitabine with or without dexamethasone pre-treatment in patients with Stage IV non-small cell lung cancer. Cancer Chemotherapy and Pharmacology 71 1375-1383. (doi:10.1007/s00280-013-2111-3)

Ritter HD, Antonova L \& Mueller CR 2012 The unliganded glucocorticoid receptor positively regulates the tumor suppressor gene BRCA1 through GABP beta. Molecular Cancer Research 10 558-569. (doi:10.1158/1541-7786.MCR-11-0423-T)

Rogatsky I, Trowbridge JM \& Garabedian MJ 1997 Glucocorticoid receptor-mediated cell cycle arrest is achieved through distinct cell-specific transcriptional regulatory mechanisms. Molecular and Cellular Biology 17 3181-3193. (doi:10.1128/MCB.17.6.3181)

Rog-Zielinska EA, Richardson RV, Denvir MA \& Chapman KE 2014 Glucocorticoids and foetal heart maturation; implications for prematurity and foetal programming. Journal of Molecular Endocrinology 52 R125-R135. (doi:10.1530/JME-13-0204)

Rutz HP 2002 Effects of corticosteroid use on treatment of solid tumours. Lancet 360 1969-1970. (doi:10.1016/S0140-6736(02)11922-2)

Schlossmacher G, Platt E, Davies A, Meredith S \& White A 2013 Glucocorticoid receptor-mediated apoptosis in small-cell lung cancer requires interaction with BCL2. Endocrine-Related Cancer 20 785-795. (doi:10.1530/ERC-13-0402)

Schmidt S, Rainer J, Ploner C, Presul E, Riml S \& Kofler R 2004 Glucocorticoid-induced apoptosis and glucocorticoid resistance: molecular mechanisms and clinical relevance. Cell Death \& Differentiation 11 (Supplement 1) S45-S55. (doi:10.1038/ sj.cdd.4401456)

Schmid-Bindert G, Gebbia V, Mayer F, Arriola E, Marquez-Medina D, Syrigos K, Biesma B, Leschinger MI, Frimodt-Moller B, Ripoche V et al. 2013 Phase II study of pemetrexed and cisplatin plus cetuximab followed by pemetrexed and cetuximab maintenance therapy in patients with advanced nonsquamous non-small cell lung cancer. Lung Cancer 81 428-434. (doi:10.1016/j. lungcan.2013.05.010)

Semenova EA, Nagel R \& Berns A 2015 Origins, genetic landscape, and emerging therapies of small cell lung cancer. Genes \& Development 29 1447-1462. (doi:10.1101/gad.263145.115)

Singh N, Taylor K, Mjoli PB, Poolman T, Ray DW \& Sommer P 2014 The N-terminal transactivation domain of the glucocorticoid receptor mediates apoptosis of human small cell lung cancer cells. Genes, Chromosomes \& Cancer 53 999-1007. (doi:10.1002/gcc.22209)

Sommer P, Le Rouzic P, Gillingham H, Berry A, Kayahara M, Huynh T, White A \& Ray DW 2007 Glucocorticoid receptor overexpression exerts an antisurvival effect on human small cell lung cancer cells. Oncogene 26 7111-7121. (doi:10.1038/sj.onc.1210524)

Sommer P, Cowen RL, Berry A, Cookson A, Telfer BA, Williams KJ, Stratford IJ, Kay P, White A \& Ray DW 2010 Glucocorticoid receptor over-expression promotes human small cell lung cancer apoptosis in vivo and thereby slows tumor growth. Endocrine-Related Cancer 17 203-213. (doi:10.1677/ERC-09-0241)
Thatcher N, Wagstaff J, Wilkinson P, Palmer M \& Crowther D 1982 Intermittent high-dose cyclophosphamide with and without prednisolone: a study of the relationships between toxicity, response and survival in metastatic lung cancer. Cancer $\mathbf{5 0}$ 1051-1056. (doi:10.1002/1097-0142(19820915)50:6<1051::AIDCNCR2820500605>3.0.CO;2-X)

Torre LA, Bray F, Siegel RL, Ferlay J, Lortet-Tieulent J \& Jemal A 2015 Global cancer statistics, 2012. CA: A Cancer Journal for Clinicians 65 87-108. (doi:10.3322/caac.21262)

Tronche F, Kellendonk C, Kretz O, Gass P, Anlag K, Orban PC, Bock R, Klein R \& Schutz G 1999 Disruption of the glucocorticoid receptor gene in the nervous system results in reduced anxiety. Nature Genetics 23 99-103.

Turner JD \& Muller CP 2005 Structure of the glucocorticoid receptor (NR3C1) gene 5' untranslated region: identification, and tissue distribution of multiple new human exon 1. Journal of Molecular Endocrinology 35 283-292. (doi:10.1677/jme.1.01822)

van den Berg RM, Teertstra HJ, van Zandwijk N, van Tinteren $H$, Visser C, Pasic A, Sutedja TG, Baas P, Golding RP, Postmus PE et al. 2008 CT detected indeterminate pulmonary nodules in a chemoprevention trial of fluticasone. Lung Cancer 60 57-61.

Vanderbilt JN, Miesfeld R, Maler BA \& Yamamoto KR 1987 Intracellular receptor concentration limits glucocorticoid-dependent enhancer activity. Molecular Endocrinology 1 68-74. (doi:10.1210/mend-1-1-68)

Veronesi G, Szabo E, Decensi A, Guerrieri-Gonzaga A, Bellomi M, Radice D, Ferretti S, Pelosi G, Lazzeroni M, Serrano D et al. 2011 Randomized phase II trial of inhaled budesonide versus placebo in high-risk individuals with CT screen-detected lung nodules. Cancer Prevention Research 4 34-42. (doi:10.1158/ 1940-6207.CAPR-10-0182)

Waffarn F \& Davis EP 2012 Effects of antenatal corticosteroids on the hypothalamic-pituitary-adrenocortical axis of the fetus and newborn: experimental findings and clinical considerations. American Journal of Obstetrics and Gynecology 207 446-454. (doi:10.1016/j.ajog.2012.06.012)

Wang Y, Zhang Z, Kastens E, Lubet RA \& You M 2003 Mice with alterations in both p53 and Ink4a/Arf display a striking increase in lung tumor multiplicity and progression: differential chemopreventive effect of budesonide in wild-type and mutant A/J mice. Cancer Research 63 4389-4395.

Wang H, Li M, Rinehart JJ \& Zhang R 2004 Pretreatment with dexamethasone increases antitumor activity of carboplatin and gemcitabine in mice bearing human cancer xenografts: in vivo activity, pharmacokinetics, and clinical implications for cancer chemotherapy. Clinical Cancer Research 10 1633-1644. (doi:10.1158/1078-0432.CCR-0829-3)

Wang Y, Wen W, Yi Y, Zhang Z, Lubet RA \& You M 2009 Preventive effects of bexarotene and budesonide in a genetically engineered mouse model of small cell lung cancer. Cancer Prevention Research 2 1059-1064. (doi:10.1158/1940-6207.CAPR-09-0221)

Xu YH, Mei JS \& Zhou J 2015 Randomized study of gefitinib versus pemetrexed as maintenance treatment in patients with advanced glandular non-small cell lung cancer. International Journal of Clinical and Experimental Medicine 8 6242-6246.

Yemelyanov A, Czwornog J, Chebotaev D, Karseladze A, Kulevitch E, Yang X \& Budunova I 2007 Tumor suppressor activity of glucocorticoid receptor in the prostate. Oncogene 26 1885-1896. (doi:10.1038/sj.onc.1209991)

Zhou J \& Cidlowski JA 2005 The human glucocorticoid receptor: One gene, multiple proteins and diverse responses. Steroids 70 407-417. (doi:10.1016/j.steroids.2005.02.006)

Received in final form 7 January 2016

Accepted 21 January 2016

Accepted Preprint published online 21 January 2016 http://joe.endocrinology-journals.org

DOI: $10.1530 / \mathrm{JOE}-15-0496$
C 2016 Society for Endocrinology Printed in Great Britain 